

\section{$4^{\text {th }}$ International Conference on}

Advancement in Engineering and

Management

(AEM-2021)

Jun 10-11, 2021

Copyright (C) 2021 International Research and Development Center for Publication

DOI: $10.22161 /$ conf.aem.jun.2021

\section{Publisher}

\section{IRDCP}

Email: irdcp.publication@gmail.com |conference.irdcp@gmail.com

Web: https://irdcp.org/ 


\section{$\underline{\text { About IRDCP }}$}

International Research and Development Center for Publication (IRDCP) is a nonprofit organization for promoting research and development around the world. IRDCP is the bridge between the quality publisher and researchers. It provides the platform to researchers and academicians for publication in the Scopus Indexed Journals, SCI Journals, Web of Science Journals, UGC Approved Journals, NAAS Rated Journals, Google Scholar Indexed Journals and other good quality DOI journals.

IRDCP is also a partner organization for publication in conference proceedings. We organize the International conferences for publication in SCOPUS indexed and other refereed journals as per the requirement of the authors of the manuscripts. The manuscripts submitted to IRDCP should be plagiarism free and well coherent in all sense.

The scope of publication with the IRDCP covers all type of review and research manuscripts including the Exploratory \& Explanatory Research, Descriptive \& Theoretical Research, Applied Research \& Action Research, Cross-Sectional Research, Quantitative \& Qualitative Research in the field of engineering \& technology, agriculture \& environmental, Social science \& Humanities, Literature \& Education development, Medical \& Health Science.

\section{The vision of IRDCP :}

IRDCP endeavors to promote global excellence in the field of research \& development through diligent applications of advanced technology for the holistic development of society. Also, IRDCP is committed to motivate and persuade the researchers to take up the projects for the continuous development of human society and make this world a better place to live in. The IRDCP has a steadfast commitment be the fulcrum of the ocean of knowledge around which efforts of researchers move about. 


\section{$\underline{\text { About Conference }}$}

\section{International Conference on Advancement in Engineering and Management (AEM-2021)}

During the worldwide lockdown due to COVID 19 pandemic, a lot of important activities have come to a halt. However, when we look at the brighter side, all of us have more time for adding to our knowledge and insights.

With this aim, to keep contributing to learning and motivation International research and development Center for publication is going to organize a two-day International Conference with the title "International Conference on Advancement in Engineering and Management (AEM-2021)" on Jun 10-11, 2021 through online mode.

We hope, this online mode of the conference in COVID-19 pandemic will be an appreciable step in promoting the research activities and new information between researchers, developers, students, academicians and practitioners working in and around the world by keeping the social distance in view to stop the spread of COVID-19 disease. This conference aims is to present the current researches being carried out in the field of social science and education development around the globe.

Prospective authors from academia as well as industry are invited to submit their abstracts that illustrate original/unpublished works and industrial applications describing advances and significant innovations in the field. 


\section{International Advisory Committee}

- Prof. Dr. Flávio de São Pedro Filho, Coordinator of the GEITEC / UNIR / CNPq, Brazil; Federal University of Rondônia, Brazil

- Kofand Anwar, American Stratford University, Virginia

- Dr. Raghvendra Singh, Pranveer Singh Institute of Technology, India

- Dr. Mohammed Y. Suliman, Northern Technical University, Iraq

- José G. Vargas-Hernández, Núcleo Universitario Los Belenes CUCEA, Zapopan, Jalisco C.P. 45100; México

- Dr. Payal Chadha, University of Maryland University College Europe, Kuwait

- Dr. K. Srujan Raju, CMR Technical Campus (CMRG), CSI State Student Coordinator, Telangana State, India

- Prof. Dr. Eng. Ahmed Kadhim Hussein, College of Engineering, Department of Mechanical Engineering, Babylon University, Babylon City, HIILA , IRAQ

- Dr. M. Kannan, SCSVMV, Kanchipuram, India

- Mr. Sagar Jamle, Oriental University Indore, India

- Monica Aparecida da Rocha Silva, Universidade de São Paulo, Brazil

- Mohammed Y. Suliman, Northern Technical University, Iraq

- Mohd Muntjir, College of Computers and Information Technology, Taif University, Kingdom of Saudi Arabia 


\section{Message}

I am extremely pleased to share that International Research and Development Center for Publication (IRDCP) is organizing a two days International Conference on Advancement in Engineering and Management (AEM-2021) on Jun 10-11, 2021.

I am sure the state of art lectures from the invited experts and the research findings of researchers, academicians, utility engineers will enrich the knowledge of all the participants. It will provide an excellent opportunity for students to learn new ideas.

I offer my best wishes to the whole team of the organizing committee, the participants, and volunteers for the grand success of the conference.

Dr. Kiran

Convenor AEM-2021 


\section{Message}

I am happy to know that International Research and Development Center for Publication (IRDCP) is organizing a two days International Conference on Advancement in Engineering and Management (AEM-2021) on Jun 10-11, 2021. I am sure that, this conference would provide an ideal platform for the academicians, scholars and experts to present and exchange their research findings and Ideas.

I wish the conference a great success.

Dr. Ahmed Ansari 
Design of MEMS Biosensor for Pathogenic Bacterial Disease Detection Ms. K. R. Katole ${ }^{1}$, Mrs. S.P Balwir ${ }^{2}$, Mr P. P Manekar ${ }^{3}$

Impact of Innovation on Projects Performance Towards Successful Implementation of Oman Vision 2040

Hamed Nasser Mubarak Al Khudhuri, ${ }^{1}$ Assoc. Prof. Ts. Dr. Sivadass A/l Thiruchelvam, ${ }^{2}$ Prof. Dato' Ir. Dr. Kamal Nasharuddin Bin Mustapha ${ }^{3}$

An investigation into effectiveness of assessment tools for engineering apprenticeship: Action research in advanced manufacturing course Dr. Sajid Khalifa 

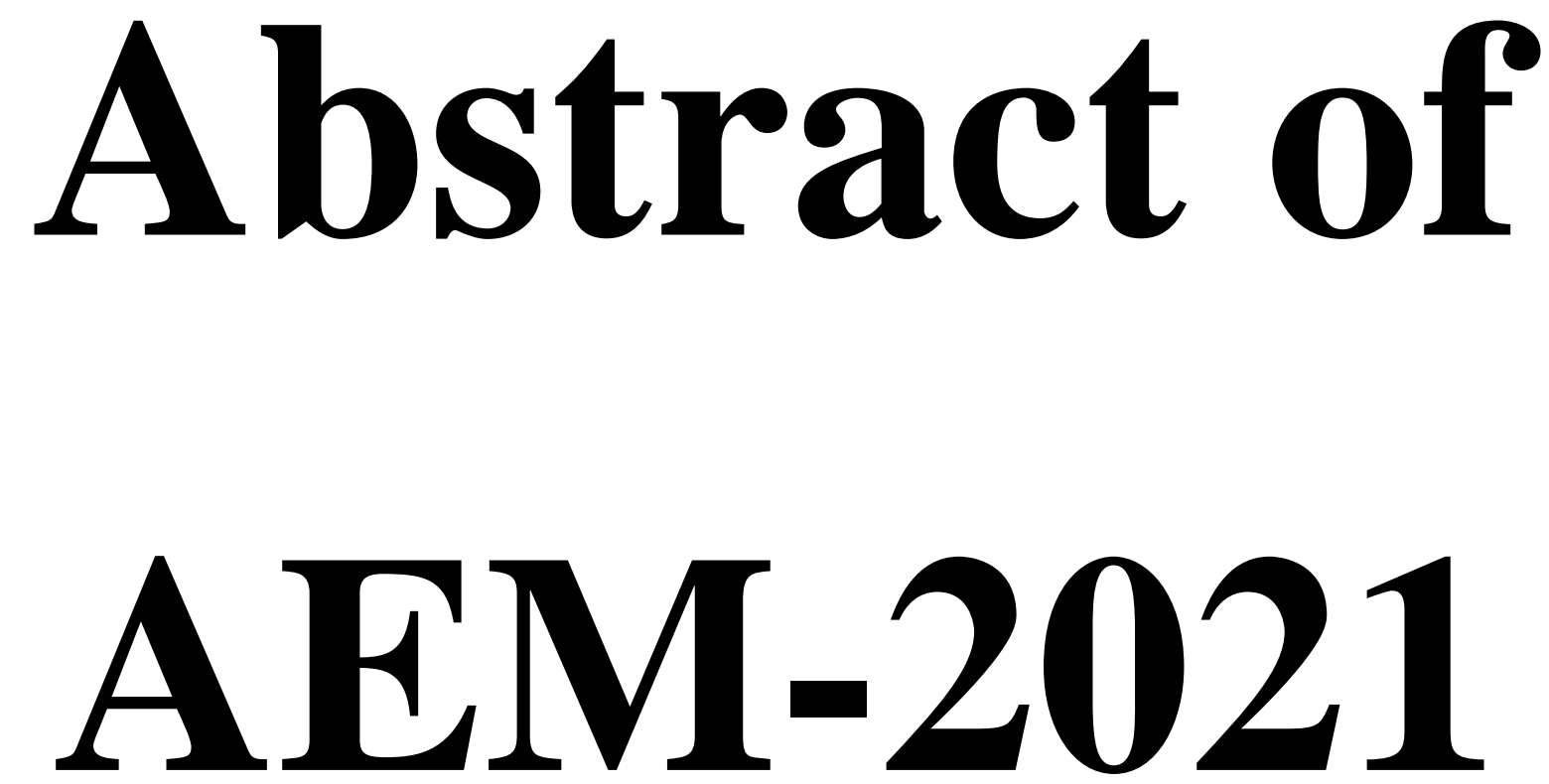


\title{
Design of MEMS Biosensor for Pathogenic Bacterial Disease Detection
}

\author{
Ms. K. R. Katole ${ }^{1}$, Mrs. S.P Balwir ${ }^{2}$, Mr P. P Manekar ${ }^{3}$ \\ ${ }^{1}$ Dr. Babasaheb Ambedkar College of Engineering \& Research, Nagpur, India. \\ ${ }^{2}$ Dr. Babasaheb Ambedkar College of Engineering \& Research, Nagpur, India. \\ ${ }^{3}$ CSIR, National Environmental Engineering and Research Institute, Nagpur, India.
}

\begin{abstract}
In situations of a critical disease outbreak, any time delay in identifying the pathogen can prove to be risky and has its far-reaching effects on public health systems. There is a need for pathogenic bacteria detection at the point-of-care (POC) using a fast, sensitive, inexpensive, and easy-to-use method that does not require complex infrastructure and well-trained technicians. For instance, detection of pneumonia, tuberculosis at acute infection stage has been challenging, since current antibody-based POC technologies are not effective due to low concentration of antibodies. In this study, we demonstrated for the first time a label-free electrical sensing method that can detect pathogenic bacteria, through MEMS cantilever technology. The presented method offers a rapid and portable tool that is MEMS biosensor, can be used as a bacteria detection technology at the hospital and primary care settings.
\end{abstract}

Keywords - Biosensor, Micro-cantilever, pathogen, MEMS

\section{References:}

[1] Erman Timurdogana, B. Erdem Alacab, I. Halil Kavaklic, Hakan Ureya,*." MEMS biosensor for detection of Hepatitis A and C viruses in serum",Biosensors and BioElectronics Elsevier

[2] Federico Hahn, "Actual Pathogen Detection: Sensors and Algorithms - a Review", algorithms ISSN 1999-4893, www.mdpi.com/journal/algorithms

[3] Chithra \& Pallavi S. \& A. Amalin Prince, "RF MEMS-Based Biosensor for Pathogenic Bacteria Detection”, BioNanoSci.DOI 10.1007/s12668-013-0098-1

[4] Hadi Shafi ee , Muntasir Jahangir , Fatih Inci, ShuQi Wang , "Acute On-Chip HIV Detection Through Label-Free

[5] Electrical Sensing of Viral Nano-Lysate", small 2013, 9, No. 15, 2553-2563

[6] A.M Moulin S. J O' Shea M.E Welland, " Microcantilever-based biosensors", Ultramicroscopy, Volume 82, Issues 1-4, February 2000, Pages 23-31

[7] Jeffary B. H. Tok, "Nano and Microsensor for chemical and biological Terrorism surveillance"

[8] Guanghua Wu, Ram H.Datar, Karolyn M.Hasen, Thomas Thundat, Richard J. Cote, Arjun Majumdar,'Bioassay of Prostate-Specific Antigen(PSA) Using Microcantilevers", Nature Biotechnology, VOL.19, No.856,2001. 
[9] Deep Kishore Parsediya, Jawar Singh, Pavan Kumar Kankar, "Simulation and analysis of highly sensitive MEMS cantilever designs for "in vivo label free" biosensing" 2nd International Conference on Innovations in Automation and Mechatronics Engineering, ICIAME 2014. 


\title{
Impact of Innovation on Projects Performance Towards Successful Implementation of Oman Vision 2040
}

\author{
Hamed Nasser Mubarak Al Khudhuri, ${ }^{1}$ Assoc. Prof. Ts. Dr. Sivadass A/1 \\ Thiruchelvam, ${ }^{2}$ Prof. Dato' Ir. Dr. Kamal Nasharuddin Bin Mustapha ${ }^{3}$
}

${ }^{1}$ College of Graduate Studies, Universiti Tenaga Nasional (UNITEN University), Putragaya, Selangor, Malaysia

${ }^{2}$ College of Graduate Studies, Universiti Tenaga Nasional (UNITEN University), Putragaya, Selangor, Malaysia

${ }^{3}$ College of Graduate Studies, Universiti Tenaga Nasional (UNITEN University), Putragaya, Selangor, Malaysia

Email Id: $\underline{\text { hnmk143@gmail.com }}$

\begin{abstract}
The incorporation of the innovation and modern technologies into the models of projects management and performance is critical to promoting the effectiveness of Orginsations. Projects Management (PM) has been the norm in the modern businesses environment. The main objective of this study is to focus on analyzing the impact of innovation (digitalization, digitization and data transformation) and the modern technologies into the projects management methodologies (Agile, Lean, Kanban and Scrum) on the overall projects performance along with the effective implementation approach in case of Oman Vision 2040 and the way it can prove to be a key element in the economic growth of Oman. Quantitative research methodologies with structural online questioners' survey and Structural Equation Model (SEM) and Smart PLS tool will be applied to test the relationships between independent, moderating and dependent variables and to analyze the collected data from all projects management professionals and practitioners of projects stakeholders (Clients, Contractors, Consultants and materials manfucutering and suppliers) in an attempt to answer the research questions. At the end, the conclusions and recommendations will be developed based on the findings. These findings will help the projects management professionals, practitioners, and Oman policies and decisions makers to develop strategies to utilize the new technologies and innovation to improve the projects performance that will help to accelerate the Oman economic growth by implementing the Oman Vision 2040 projects and investments opportunities effectively.
\end{abstract}

Keywords - Economic Growth, Innovation Practices, Oman Vision 2040, Projects Management Applications.

\section{References:}

[1] Alam, M., \& HUSSEIN, M. A. (2019). The impact of capital market on the economic growth in Oman. Financial Studies, 2, 116-129. 
[2] Alawamleh, M., Ismail, L., Nahleh, M., \& Qudah, K. (2020). Role of open innovation in project management CSF. International Journal Of Business Innovation And Research, 21(4), 466. https://doi.org/10.1504/ijbir.2020.106013.

[3] Allahar, H. (2019). A Management Innovation Approach to Project Planning. Technology Innovation Management Review, 9(6), 4-13. https://doi.org/10.22215/timreview/1245.

[4] Al Nabhani, S. K. M., Taderera, F., \& Somasundaram, B. (2015). Analysing innovative practices for Oman firms to excel on global markets and networking and linking with higher education. The Business \& Management Review, 6(3), 93. Retrieved from http://www.abrmr.com/myfile/conference_proceedings/Con_Pro_42356/2015roge15.pdf

[5] ALSiyabi, N. H., \& Goel, N. (2019). The Effectiveness of Knowledge Management and Business Intelligence for Increasing Financial Performance. (A Case Study: Petroleum Development Oman). Journal of Student Research.

[6] AP NEWS. (2021). Oman Construction Industry Market Size \& Forecasts to 2024, by Value and Volume Across 40+ Market Segments - ResearchAndMarkets.com. AP NEWS. $\quad$ Retrieved $21 \quad$ May $2021, \quad$ from https://apnews.com/pressrelease/businesswire/52840ffc64d44f3193e1547748c32c41

[7] Aubry, M., \& Hobbs, B. (2019). A fresh look at the contribution of project management to organizational performance. Project management journal, 42(1), 3-16.

[8] Intelligence, M. (2020). Oman Construction Market | Growth, Trends, and Forecast (2019 - 2024). https://www.mordorintelligence.com/industry-reports/oman-constructionmarket. 


\title{
An investigation into effectiveness of assessment tools for engineering apprenticeship: Action research in advanced manufacturing course
}

\author{
Dr. Sajid Khalifa \\ Effat University, Jeddah, Makkah region, Saudi Arabia \\ Email Id: sakhalifa@effatuniversity.edu.sa
}

\begin{abstract}
The City and Guilds qualification is an integral part of the UK vocational qualification framework. The Advanced and Higher apprenticeship is the backbone of vocational qualification where the new generation of engineers get trained in the Further Education colleges by pursuing Level 3 qualification after completing the secondary education. Mathematics plays an essential role within the education and engineering profession, which is used as an investigation tool in current research. This study aims to investigate the impact of various assessments, including diagnostic assessment conducted before starting a training program. It is a first attempt to set up the framework through the action research methodology to identify the underpinning issues that negatively affect the students' performance in the apprenticeship program. Level 3 advanced engineering apprenticeship students were assigned a generic task to solve simple engineering math problems with three categories of questions, "General," "Mixed," and "Subject-specific" type, in two-phase tests. The results revealed that general math questions were found to be familiar to the participants while more industry-specific questions took longer or some learners failed to resolve them. Based on the results obtained, it is identified that the specific engineering calculations are found to be difficult for students to solve, where the math application is not clearly taught as part of the general education in schools. Therefore, introducing these topics as "Masterclasses" before the actual apprenticeship training begins will benefit the learners throughout the education and engineering career, until the education board take the specific issues into consideration and update the national curriculum.
\end{abstract}

Keywords- Action research; assessment methods; diagnostic test; engineering math; master classes; vocational training.

\section{References:}

[1] Daisy T. Emanuel, (2012) An Action Research The Effect of Computer-based Mathematics on Problem Solving; Contact Information: 3rd Grade Teacher Sadie Tillis

[2] Ivie, S. D. (1998). Ausubel's learning theory: An approach to teaching higher order thinking skills. The High School Journal, 82(1), 35.

[3] Jasmin Schlax, Olga Zlatkin-Troitschanskaia, Roland Happ, Hans Anand Pant, Judith Jitomirski, Carla Kühling-Thees, Manuel Förster, Sebastian Brückner, Validity and fairness of a new entry diagnostics test in higher education economics, Studies in Educational Evaluation, Volume 66, 2020, 100900, ISSN 0191-491X 
[4] Kerri Wright (2004) An investigation to find strategies to improve student nurses' maths

[5] Ke, F. and Grabowski, B. (2007), Gameplaying for maths learning: cooperative or not? British Journal of Educational Technology, 38: 249-259. doi: 10.1111/j.14678535.2006.00593.x

[6] Peter Sullivan (2011), Australian Education Review; Teaching Mathematics:

[7] Robyn Madison-Harris and Ada Muoneke (2012) A publication of the Southeast Comprehensive Center at SEDL January 2012

[8] Using research-informed strategies; Australian Council for Educational Research 19 Prospect Hill Road, Camberwell, Victoria, 3124 


\title{
Study of Public Transportation of the city of Campinas, using the smart city concept, and specific Equipment, for the accurate data collection, and improving this Segment in the Ergonomic Concept
}

${ }^{1}$ Gabriel Gomes de Oliveira ${ }^{1}$, Yuzo Iano ${ }^{2}$, Diego Pajuelo ${ }^{2}$, Daniel Katz ${ }^{2}$, Euclides Chuma ${ }^{2}$, Michell Miranda ${ }^{2}$ and Daniel Izario ${ }^{2}$

State University of Campinas, São Paulo, Brazil

“This study was financed in part by the Coordenação de Aperfeiçoamento de Pessoal de Nivel Superior Brasil (CAPES) - Finance Code 001"

\begin{abstract}
The focus of the analysis is the public transport of the municipality, specifically the bus line No. 330, (Central Corridor / Central Terminal / Unicamp by Bus), can be replicated to other city lines, other municipalities of the MRC (Metropolitan Region of Campinas) and even other national and international municipalities. To achieve the objective of this work, a descriptive and comparative analysis method was used, taking taking into account the perspective of the city's public sector. With this, it is intended to take the reflection to the public management of the city, to obtain public transport in an intelligent way, it is necessary to achieve its sustainable and more qualified, efficient and comfortable development for its customers and third parties.
\end{abstract}

Keywords - Smart Cities, Government, Sustainable Development, Quality of Life, Revolution, Public Transport, Predictions, Transport Quality.

\section{References:}

[1] K. Jack, "One day I will be reborn in a great ...".

[2] WWF, "Sustainability".

[3] "ECOLOGICAL - FOR AN ENTIRE ENVIRONMENT," 2011.

[4] ECOLOGY - FOR AN ENTIRE ENVIRONMENT, "SUSTAINABILITY - FROM THEORY TO PRACTICE," 2011.

[5] NATURAL FIBER - Natural Furniture and Decorations, 2010.

[6] BRAZILIAN NETWORK OF INTELLIGENT CITIES, "What is a smart city?". 
[7] Environment Energy environment, sustainability and innovation. , "Solar energy and electric vehicles are some of the attractions of Itaipu at Smart City Expo Curitiba 2018," Curitiba, 2018.

[8] Piraí Inteligente, "Welcome to Piraí a smart and connected city,” Piraí, 2020. 


\title{
Improvement of the effectiveness and efficiency of the School by mobilizing digital tools
}

\begin{abstract}
Sandro Serpa ${ }^{1}$
${ }^{1}$ Faculty of Social and Human Sciences, Department of Sociology, University of the Azores; Interdisciplinary Centre of Social Sciences - CICS.UAc/CICS.NOVA.UAc; Interdisciplinary Centre for Childhood and Adolescence - NICA - UAc, the Azores, Portugal Email Id: sandro.nf.serpa@uac.pt

Abstract - The School culture tends to be deeply conservative, reproducing, to a certain extent and in a general way, the artifacts, behaviours and values that shape it. This presentation, which builds on recent studies carried out by the author, as well as on a bibliographic collection, aims to expose the main challenges that emerge when trying to improve the effectiveness and efficiency of the School through the mobilization of digital tools. It is concluded, in a word, that the diffusion of digital literacy by students - but also by the School's teachers and staff - is crucial for this process, which seems to us unstoppable for a School to be successful.
\end{abstract}

Keywords - School, effectiveness, efficiency, school culture, digital literacy, digital media tools

\section{References:}

[1] Ferreira, C. M., \&Serpa, S. (2018). Society 5.0 and Social Development: Contributions to a Discussion. Management and Organizational Studies, 5(4), 26-31. https://doi.org/10.5430/mos.v5n4p26

[2] Sá, M. J., \& Serpa, S. (2018). Transversal Competences: Their Importance and Learning Processes by Higher Education Students. Education Sciences, 8(3), 126. 1-12. https://doi.org/10.3390/educsci8030126

[3] Santos, A. I, Ferreira, C. M., Sá, M. J., \&Serpa, S. (2019), Reading on Paper and Scrolling Text on a Screen in Academic Learning.Academic Journal of Interdisciplinary Studies, 8(3), 135-143. doi:10.2478/ajis-2019-0053 
[4] Santos, A. I., \& Serpa, S. (2020). Flipped Classroom for an Active Learning. Journal of Education and E-Learning Research,7(2), 167-173. doi:10.20448/journal.509.2020.72.167.173

[5] Santos, A. I., \&Serpa, S. (2020). Literacy: Promoting Sustainability in a Digital Society. Journal of Education, Teaching and Social Studies, 2(1), 1-9. doi:10.22158/jetss.v2n1p1

[6] Serpa, S. (2016). An Overview of the Concept of Organisational Culture. International Business Management, 10(1), 51-61.

[7] Serpa, S., \& Sá, M. J., \& Ferreira, C. M. (2020). Organizational Learning Culture in Effective Improvement of Educational Organizations. The International Journal of Educational Organization and Leadership, 27(1), 47-68. doi:10.18848/23291656/CGP/v27i01/47-68

[8] Serpa, S., Santos, A. I., \& Ferreira, C. M. (2020). Contributions of Ivan Illich to Education in a Digital Society. Academic Journal of Interdisciplinary Studies, 9(2), 2330. https://doi.org/10.36941/ajis-2020-0019 


\title{
Design of InGaAs/GaAsSb quantum well structure for the NIR applications
}

\author{
Jayprakash Vijay ${ }^{1,2}$, Amit Rathi $^{1}$ \\ ${ }^{1}$ Department of Electronics and Communication Engineering, Manipal University Jaipur \\ 303007, Rajasthan, India \\ ${ }^{2}$ Department of Electronics and Communication Engineering, Swami Keshvanand Institute \\ of Technology, Management \& Gramothan, Jaipur \\ E-Mail: jpvijay121@gmail.com
}

\begin{abstract}
In this work, we have designed InGaAs/GaAsSb nanoscale heterostructure and analyses have been modeled on the GaAs substrate at room temperature $300 \mathrm{~K}$. In this structure InGaAs is a quantum well material and GaAsSb is the barrier material. The designed structure is modeled using the 6 band k.p. method to find the energy wave functions and optical gain. An optical gain of $6750 / \mathrm{cm}$ is obtained at $1520 \mathrm{~nm}$ wavelength. A high gain is needed in order to increase output power. To compute the optical gain the carrier internment and their localities are calculated. The designed structure is able to emit to radiation of NIR wavelength, so can be used for different NIR applications.
\end{abstract}

Keywords - InGaAs, GaAsSb, Heterostructure, NIR, Quantum well.

\section{References:}

[1] A.K. Singh, Md. Riyaj, S.G. Anjum, Nisha Yadav, Amit Rathi, M.J. Siddiqui, P.A. Alvi, Anisotropy and optical gain improvement in type-II In0.3Ga0.7As/GaAs0.4Sb0.6 nano-scale heterostructure under external uniaxial strain, Superlattices and Microstructures 98 (2016) 406-415.

[2] H.K. Nirmal, Nisha Yadav, F. Rahman, P.A. Alvi, Optimization of high optical gain in Type-II In0.70Ga0.30As/GaAs0.40Sb0.60 lasing nano-heterostructure for SWIR applications, Superlattices Microstruct. 88 (2015) 154-160.

[3] H.K. Nirmal, Nisha Yadav, S. Dalela, Amit Rathi, M.J. Siddiqui, P.A. Alvi, Tunability of optical gain (SWIR region) in Type-II In0.70Ga0.30As/GaAs0.40Sb0. 60 nano- 
heterostructure under high pressure, Phys. E Low Dimens. Syst. Nanostruct. 80 (2016) $36-42$.

[4] Chia-Hao Chang, Zong-Lin Li, Hong-Ting Lu, Chien-Hung Pan, Chien-Ping Lee, Gray Lin, Sheng-Di Lin, Low-threshold short-wavelength infrared InGaAs/GaAsSb 'W'Type QW laser on InP substrate, IEEE Photonics Technol. Lett. 27 (3) (2015) 225-228.

[5] P.A. Alvi, Strain-induced non-linear optical properties of straddling-type indium gallium aluminum arsenic/indium phosphide nano-scale heterostructures, Mater. Sci. Semicond. Process. 31 (2015) 106-115. 


\title{
Sociology of Organizations, challenges and opportunities
}

\author{
Sandro Serpa ${ }^{1}$
}

${ }^{1}$ Faculty of Social and Human Sciences, Department of Sociology, University of the Azores; Interdisciplinary Centre of Social Sciences - CICS.UAc/CICS.NOVA.UAc; Interdisciplinary Centre for Childhood and Adolescence - NICA - UAc, the Azores, Portugal Email Id: sandro.nf.serpa@uac.pt

\begin{abstract}
Sociology of Organizations lives. This is, to us, a basic assumption, at a time of someblurriness and reduction of its public recognition. In this presentation, we will discuss this situation, highlighting some of the challenges that arise.For this purpose we will discuss aspects such as: the object of Sociology, the specificities of Sociology of Organizations, the importance of classic authors due to their potential heuristic capacity to the analysis of organizations. It culminates in the indication of some challenges and opportunities of Sociology of Organizations.
\end{abstract}

Keywords - Sociology of Organizations, organizational studies, organizational theories, heuristic capacity

\section{References:}

[1] Ferreira, C. M., \& Serpa, S. (2018). Society 5.0 and Social Development: Contributions to a Discussion. Management and Organizational Studies, 5(4), 26-31. doi: $10.5430 / \operatorname{mos} . v 5 \mathrm{n} 4 \mathrm{p} 26$

[2] Ferreira, C. M., \& Serpa, S. (2019). Rationalization and Bureaucracy: Ideal-Type Bureacracy by Max Weber. Humanities \& Social Sciences Reviews, 7(2), 187-195. doi: $\underline{10.18510 / \text { hssr. } 2019.7220}$

[3] Serpa, S. (2016). Organization as an Analytical Level for Investigation Organizational Culture. The Social Sciences. 11(13), 3257-3263.

[4] Serpa, S. (2016). An Overview of the Concept of Organisational Culture. International Business Management, 10(1), 51-61.

[5] Serpa, S., \& Ferreira, C. M. (2019). Sociology as Scientific Knowledge. Journal of Educational and Social Research, 9(3), 178-184. doi:10.2478/jesr-2019-0035

[6] Serpa, S., \& Ferreira, C. M. (2019). Sociology of Organizations: potential and challenges. Humanities \& Social Sciences Reviews, 7(2), 165-169. doi:10.18510/hssr.2019.7217 
[7] Serpa, S., \& Ferreira, C. M. (2020). Mobilization of the Classics in Sociology. Journal of Educational and Social Research, 10(3), 35-40. doi10.36941/jesr-2020-0043

[8] Serpa, S., Ferreira, C. M., \& José Sá, M. (2020). The Potential of Organisations' SWOT Diagnostic Assessment. Academic Journal of Interdisciplinary Studies, 9(4), 93-104. doi:10.36941/ajis-2020-0065 


\title{
Determinants of SME's financing and capital structure: new evidence of the Portuguese market
}

\author{
Adalmiro Pereira ${ }^{1}$, Ângela $\mathrm{Vaz}^{2}$, Carlos Mota $^{3}$, Diogo Moutinho ${ }^{4}$ \\ ${ }^{1}$ ISCAP - P.PORTO, CEOS,Porto, Portugal \\ ${ }^{2}$ ISCAP - P.PORTO, CEOS, Porto, Portugal \\ ${ }^{3}$ U.VIGO, Vigo, Espanha \\ ${ }^{4}$ ISCAP - P.PORTO, Porto, Portugal
}

Email Id: adalmiropereira@mail.telepac.pt

\begin{abstract}
This paper studies the financial practices of SMEs in Portugal, their preferences in financing and capital structure's decisions. It analyses relations between debt levels and the determinants that explain it, using indicators based on book values. The methodology consists in the estimation of the multiple linear regression model using the least squares method for fixed effects and the generalized moment estimator (GMM). The sample consists of annual data from two panels - "PME Líder" and "PME Excelência" - representative of the various sectors of activity, in a four-year time observation (2013 to 2016).

Our study shows that SMEs tend to use short-term debt. Moreover, the evidence confirms that debt patterns can be explained by specific corporate characteristics. Profitability, liquidity and tangibility are relevant determinants of SME's capital structure. Other factors that have shown significant statistical associations with debt options are company's size and growth. Age was weakly associated with the total indebtedness of the SMEs studied. Crossdate with the main sectors of economic activity do not identify significant statistically differences in debt levels across sectors. Similarly, no significant differences between SMEs were observed in the three main Portuguese regions.
\end{abstract}

Keywords - Indebtedness, capital structure, SMEs, Portugal.

\section{References:}

[1] Ang, JS, Cole, RA, \& Lawson, D. (2010). The role of owner in capital structure Decisions: an analysis of single-owner corporations. Journal of Entrepreneurial Finance, $14,1-36$. 
[2] Chen, JJ (2004). Determinants of capital structure of Chinese-listed companies. Journal of Business Research, 57 (12), 1341-1351

[3] De Jong, A., Kabir, R., \& Nguyen, TT (2008). Capital structure around the world: The roles of firm-and country-specific determinants. Journal of Banking and Finance, 32 (9), 1954-1969.

[4] Degryse, H., of Goeij, P., \& Kappert, P. (2012). The impact of firm and industry characteristics on small Firms' capital structure. Small Business Economics, 38 (4), 431 447.

[5] Fama, EF, \& French, KR (2002). Testing trade-off and pecking order predictions about dividends and debt. The financial review of studies, 15 (1), 1-33.

[6] Flannery, MJ (2006). Partial adjustment toward target capital structures. Journal of Financial Economics, 79 (3), 469-506.

[7] Psillaki, M., \& Daskalakis, N. (2009). Are the determinants of capital structure or firm specific country? Small business economics, 33 (3), 319-333.

[8] Rajan, RG, \& Zingales, L. (1995). What do we know about capital structure? Some evidence from international date. The Journal of Finance, 50 (5), 1421-1460. 


\title{
Intangible assets that add tangible value and their relationship to the economic efficiency and financial performance of a Cuban enterprise
}

\author{
Naivi Montane Marsal \\ Wuhan University of Technology, Wuhan city, China and Havana University of Technology \\ Jose Antonio Echeverria, Havana city, Cuba, \\ Email Id: naivimontane@ @otmail.com
}

\begin{abstract}
An empirical study was conducted at a Cuban financial institution. We study the national and international theoretical models of intangible assets in the modern enterprise and its importance to generate value in the organization based on the premise that if you can't measure intellectual capital you can't manage it which is determine whether intangible assets are adding or destroying value in the organization. The results of the metrics applied were triangulated, and revealed that there is no significant relationship between the economic performance of the bank branch and the perception of the management of intangible assets by the leaders, the average scores denote low management of intangibles so in the short term they deserve to generate alerts to avoid in the long term contractions in
\end{abstract}

Keywords - Economic performance 1, Intangible assets 2, Tangibles assets 3, human capital indices 4.

\section{References:}

[1] Abdifatah A., Nazli A. (2018). The role of intangible assets and liabilities in firm performance: empirical evidence. Journal of Applied Accounting Research. Vol. 19 No. 1, 2018. pp. 42-59. DOI 10.1108/JAAR-12-2015-0108

[2] Borrás P., Ruso F. (2015). Capital intelectual: visión crítica y propuesta para organizaciones cubanas. 2015. Editorial UH. La Habana Cuba

[3] Brooking, A. Intellectual Capital: Core Assets for the Third Millenium Enterprises(1996). International Thomson Business Press, London.

[4] Catalfo P.(2016). Intangibles disclosure in management commentary regulation in Germany and Italy. Journal of Intellectual Capital. Vol.17. No. 1. 2016. DOI 10.11108/JIC-09-2015-0083. 
[5] Cozzo B., Dumay J., Palmaccio M., Lombardi R. (2017). Intellectual capital disclosure a structured literature review. Journal of Intellectual Capital, Volumen 18, No. 1, 2017. DOI 10.1108/JIC-10-2016-0104. p. 9-28.

[6] Cuesta A. (2014). Valencia M. Indicadores de gestión humana y del conocimiento en la empresa. 2014. Ediciones ECOE. Colombia

[7] Cuesta, A. (2017). Gestión del talento humano del conocimiento, Segunda edición, 2017 Bogotá: ECOE Ediciones. ISBN: 978-958-771-379-4

[8] Kaplan r \& Norton D. (2004). Strategic maps.. Harvard business school Publishing Corporation. EUA 


\title{
Short-term Load Forecasting Using Combined Weather Stations
}

\author{
Guilherme Guilhermino Neto ${ }^{1}$, Henrique Steinherz Hippert ${ }^{2}$ \\ ${ }^{1}$ Federal Institute of Espírito Santo, Linhares, ES, Brazil \\ ${ }^{2}$ Federal University of Juiz de Fora, Juiz de Fora, MG, Brazil \\ Email Id: guilherme.neto@ifes.edu.br
}

\begin{abstract}
In order to schedule the load generation and distribution, operators of energy markets rely on short-term load forecasts (STLF), specially those made for the next few hours. Since it is not feasible to store a large energy volume for compensating unbalances between supply and demand, what lacks or remains must be exchanged with an interconnected system for last time price quotation. Transactions like these raise the costs not only for the operator, but for the whole supply chain; for which reason STLF has been a major concern for practicioners and researchers for years. The behavior of load series is wellknown (mostly influenced by weather variables), and a wide range of techniques, from statistical time series models to neural networks, have proven capable to produce accurate forecasts. Regardless, STLF remains a widely discussed topic, seeing that minimal improvement may lead to great cost decrease, and also that new practical issues have been emerging from the replacement of old systems by smart technologies. One of the new interests in this field is the hierarchical load forecasting. The latest smart grid systems made possible to monitor real-time load at various levels of aggregation, from households to the whole system, bringing the interest towards forecasting not only the load for the whole system, but also for all levels. Some levels may comprise large geographical zones, on which more than one weather station may be located, and that raises a question: how to combine data from more than one weather station to use as input for load forecasting models? On this paper, we combine weather stations by giving more weight to those closer to the centroid of the load zone. We experiment on data from a load zone in the state of New York and 11 weather stations spread throughout the state, using the combined data as input for neural networks. For our data, the proposed combinations lead to better results than those from neural networks that use of any of the 11 stations individually. Also, the proposed method outperforms several statistical time series benchmarks.
\end{abstract}

Keywords - load forecasting, weather variables combination, neural networks, time series, hierachical load forecasting. 


\section{References:}

[1] Ben Taieb, S., Taylor, J.W., Hyndman, R.J. (2020) Hierarchical probabilistic forecasting of electricity demand with smart meter data, Journal of the American Statistical Association (forthcoming)

[2] Caro, E., Juan, J., Cara, J. (2020). Periodically correlated models for short-term electricity load forecasting, Applied Mathematics and Computation. 364, 124642

[3] Cretì, A., Fontini, F. (2019). Economics of Electricity: Markets, Competition and Rules. Cambridge, UK: Cambridge University Press.

[4] Hippert, H.S., Pedreira, C.E., Souza, R.C. (2001). Neural networks for short-term load forecasting: A review and evaluation, IEEE Transactions on Power Systems. 16 (1), 4455

[5] Hong, T., Wang, P., White, L. (2015). Weather station selection for electric load forecasting, International Journal of Forecasting. 31 (2), 286-295

[6] Hong, T., Fan, S. (2016). Probabilistics electric load forecasting: A tutorial review, International Journal of Forecasting. 32 (3), 914-938

[7] Sobhani, M., Campbell, A., Sangamwar, S., Li, C., Hong, T. (2019). Combining Weather Stations for Electric Load Forecasting, Energies. 12, 1510

[8] Weron, R. (2006). Modeling and Forecasting Electricity Loads and Prices: A Statistical Approach. Chichester, UK: Wiley 